\title{
EL PAPEL DE LA ESCUELA EN LA CONSTRUCCIÓN DE LA NACIONALIDAD EN COLOMBIA. UNAAPROXIMACIÓN A LA ESCUELA ELEMENTAL, 1900-1930*
}

\author{
Mgs. Doris Lilia Torres Cruz ${ }^{1}$ \\ Universidad Pedagógica y Tecnológica de Colombia \\ Grupo de Investigación HISULA \\ dorislilia6@yahoo.com
}

Recepción: 04/09/2009

Evaluación: 09/10/2009

Aceptación: 18/11/2009

Artículo de Reflexión

\section{RESUMEN}

Este artículo es el resultado de una investigación sobre el proyecto de construcción de nación en los textos escolares usados durante las tres primeras décadas del siglo XX en Colombia. En esta ocasión se ofrece una aproximación a los maestros, sus métodos y los libros que usaron, con el fin de ambientar las prácticas discursivas de la élite frente a la diversidad cultural, masiva y popular del momento.

Palabras clave: Educación, libro, escuela elemental, tácticas

\footnotetext{
* Este artículo es un producto parcial del proyecto de investigación "Educadores en América Latina y el Caribe Siglos XVI a XXI" del grupo de investigación HISULA, financiado por COLCIENCIAS - Código COLCIENCIAS 110945221355 - SGI 699.

1 Licenciada, Magíster en Lingüística y Candidata a Doctor del Doctorado en Ciencias de la Educación-RUDECOLOMBIA, integrante del grupo de investigación Historia y Prospectiva de la Universidad latinoamericana HISULA.
} 


\title{
THE SCHOOL ROLE IN THE COLOMBIAN NATION PROJECT. AN APPROACH TO THE PRIMARY SCHOOL, 1900-1930
}

\author{
Mgs. Doris Lilia Torres Cruz ${ }^{1}$ \\ Universidad Pedagógica y Tecnológica de Colombia \\ Grupo de Investigación HISULA \\ dorislilia6@yahoo.com
}

\begin{abstract}
This article is the result of a research about the nation construction Project on the school texts used along the first three decades of the 20th century in Colombia. This paper shows the teaching practice, methods and books that were used in order to offer a context related to the nation Project.
\end{abstract}

Key words: Education, book, primary school, strategies.

\section{INTRODUCCIÓN}

El presente artículo recoge algunas ideas expuestas en un trabajo más extenso acerca de La enseñanza de la lengua castellana en Colombia, 1900-1930, en estado de elaboración como tesis de doctorado en Ciencias de la Educación. Específicamente, el estudio del maestro junto con sus métodos, tácticas y libros escolares apunta a caracterizar el contexto educativo del nivel elemental, con el fin de plantear que el modelo establecido por la política educativa no correspondía con las circunstancias sociales del momento. Es decir, que el analfabetismo reinante en las primeras décadas unido al deterioro económico, social y educativo dejado por la Guerra de los mil días, abonó el terreno para llevar a cabo la Ley Orgánica de Educación y su subordinación a la doctrina de la Religión Católica y al Estado, tal como lo estipulaban la Constitución de 1886 y el Concordato 1887. Así mismo, se busca mostrar el papel que cumplieron los maestros de la escuela elemental para la enseñanza, entendiendo que a través de ellos se transmitieron y configuraron los sentidos y significados para la construcción 
de la nación. Para tal fin, en la primera parte se hará mención a la legislación escolar a comienzos del siglo XX; en la segunda se mencionarán los métodos y las tácticas escolares utilizadas por los maestros de la enseñanza elemental y, en la tercera y última parte, se presentarán los libros escolares que compilaron algunas lecturas que hicieron los maestros del país.

\section{Legislación escolar a comienzos del Siglo $X X$}

Cuando se dividió la instrucción pública en primaria, secundaria, industrial y profesional, se exigió que la primaria fuera difundida obligatoriamente por los gobiernos departamentales en todo el territorio nacional y, que de una manera práctica se enseñaran las nociones elementales que habilitaban para el ejercicio de la ciudadanía y preparaban para la agricultura, la industria fabril y el comercio. En el caso de la secundaria, la Ley tenía por misión "la educación cristiana de los niños a través de la catequización de las masas," " la cual se hacía obligatoria en todos los grados y niveles, tanto que los aprendices debían confesar personalmente su creencia, participar en el culto y recitar las oraciones "al pie de la letra".

La Ley 39 de 1903, y en el Decreto Reglamentario 491 de 1904, capítulo IV, Art. $5^{\circ}$, en las Juntas de Inspección era obligatoria y primordial la presencia del Cura Párroco del Municipio respectivo. El sacerdote definía el nivel en el cual cada niño debía estar y si se podía reconocer como un sujeto admitido dentro de la escuela, siempre y cuando aprendiera al pie de la letra el catecismo y las oraciones de la iglesia; de lo contrario se excluía del mundo escolar y en muchos casos quedaba al margen de la sociedad adulta. La Nación inspeccionaba y financiaba la secundaria, la industrial y profesional. La instrucción primaria quedaba definida como "esencialmente práctica" y orientaba a dotar al alumno de las "nociones elementales que lo habilitaban para el ejercicio de la ciudadanía y lo preparaban para la agricultura, la industria y el comercio."” La secundaria fue a su vez especializada en técnica (cultura general, idiomas, materias profesionales) y clásica (filosofía y letras) aunque se recomendaba fomentar prioritariamente la instrucción técnica.

La entidad encargada de la enseñanza industrial y comercial, se debía preocupar por la fundación de escuelas de artes y oficios, donde se adiestrarían los estudiantes en la manufactura y "en el manejo de máquinas aplicables a las pequeñas industrias."” Por último, la instrucción profesional sería dada por la Facultad de Filosofía y Letras del Colegio Mayor del Rosario, el cual era autónomo en sus decisiones alrededor de las Facultades de Medicina, Ingeniería, Derecho, la Escuela de Veterinaria y el Colegio Dental. Se creó, igualmente, el Consejo Universitario como cuerpo consultivo nombrado por el Presidente de la República.

2 CHARTIER, Anne Marie. (2004): Enseñar a leer y escribir. Una aproximación histórica. México: Fondo de Cultura Económica. p.36

3 MINISTERIO DE EDUCACIÓN. (1959): Educación Colombiana 1903-1958. Imprenta Nacional, Bogotá. p. 9.

4 Ibídem, p. 10. 
El Decreto 491 de 1904, el cual modificaba el Artículo 40 de la Ley 39 de 1903, estipulaba que cualquier perfeccionamiento posterior de la norma debería "descansar sobre la triple base de la educación moral y religiosa en todos los estudios; de la educación industrial en la primaria y la secundaria; y de los estudios profundos, severos y prácticos en la instrucción profesional." ${ }^{\prime 5}$ El Decreto legisló sobre múltiples aspectos del sistema educativo: las atribuciones del ministro del ramo, de los secretarios de instrucción pública, del Consejo Universitario y sobre las modalidades de la inspección y organización de la enseñanza primaria, secundaria y profesional. Fue particularmente minucioso en lo referente a la escuela elemental, que clasificó en rural y urbana y precisó diversos tópicos tales como la catequización de indígenas, el sostenimiento de las escuelas, el número de niños permisibles en cada una de ellas, la edad escolar y el plan de estudios. Según el Decreto 491 de 1904, la enseñanza primaria debía integrar la educación moral, cuyo fin "era la práctica de los deberes para con Dios, para consigo mismo, para con los padres y superiores, para con los semejantes y para con la patria"; con la educación intelectual, "que desarrollaba en el niño el conjunto de facultades mentales"; y con la educación cívica y física. ${ }^{6}$ Basado en estas orientaciones, se definió el plan de estudios de la primaria diferenciando la escuela rural de la urbana, el pensum para niños y para niñas, y las materias para cada nivel. La escuela rural constaría en adelante de un ciclo de tres años, y la urbana por uno de seis años dividido en tres niveles: elemental, medio y superior. Las diferencias curriculares entre la escuela rural y urbana podían ser ilustradas en las asignaturas estipuladas para el primer año: en la rural, el niño aprendía religión, lectura, escritura, aritmética y urbanidad; en la urbana, a las anteriores materias se agregaban dibujo lineal, canto, lecciones objetivas, "calistenia" y "obras de mano". El Decreto legisló también sobre los textos. Estableció que éstos debían ser aprobados por una junta de pedagogos y por el Arzobispo de Bogotá; quienes a su vez también determinaban y definían los deberes de los maestros, los requisitos de la matrícula y asistencia, los exámenes y el sistema correccional. Todo lo anterior basado en el principio de la moral católica, apostólica y romana.

En relación con la instrucción secundaria, la reglamentación de 1904 fue menos amplia, e hizo referencia básicamente a los planes de estudio de las escuelas normales, de la instrucción técnica y de la clásica, así como a la fundación de la Revista de Instrucción Pública. Las escuelas normales tenían como objeto la formación de maestros de primaria y deberían existir en cada departamento, siendo la Escuela Normal de Cundinamarca la encargada de formar el personal docente para todas las otras normales. El conjunto de materias del plan estaba orientado "a la adquisición de nociones suficientes no sólo en el orden moral e intelectual sino también en los principios aplicables a la industria, la agricultura y el comercio"7 La instrucción técnica comprendía materias vinculadas con las ciencias naturales y con las matemáticas y guiadas por el "método empírico". La secundaria clásica por el contrario, poseía una orientación más teórica y especulativa. Vista en su conjunto la reforma fue una expresión directa de los

\footnotetext{
Ibídem, p. 25

Ibídem, p. 26.

Ibídem, p. 27.
} 
fundamentos constitucionales formulados por Núñez y Caro, donde predominan tres elementos: la unidad nacional, la preeminencia de la Religión Católica, y el "fomento de la riqueza". Ciertamente la Reforma Uribe tenía el antecedente inmediato del Plan Zerda de 1892, que inspirado también en la Constitución del 86 y en el Concordato del 87, pretendió unificar el sistema educativo, dotar al Estado de instrumentos que hicieran viable la "Suprema inspección y reglamentación de la enseñanza", tal como lo ordenaba el Artículo 41 de la Constitución, y dar cumplimiento a los artículos 12 y 13 del Concordato que supeditaban la organización de la educación pública a la Iglesia. Pero Uribe fue más allá al lograr una mayor organicidad del plan anterior ${ }^{8}$ y sobre todo, al deducir la ley del proyecto hegemónico que el conservatismo había formulado como consecuencia del triunfo en la Guerra de los Mil días. ${ }^{9}$ Después de la guerra, la unidad nacional que los constituyentes del 86 habían buscado por medio de la centralización política, y del intervencionismo se hacía no sólo necesaria, sino posible con la derrota del liberalismo. Unidad, centralización e intervencionismo eran los ejes sobre los cuales giraba el proyecto político conservador.

La unificación de la Nación y del Estado no dependía solamente de la centralización política. Era también un problema de unidad espiritual, ideológica y lingüística. La Iglesia Católica como poder real, centralizado y jerarquizado y como doctrina ideológica unitaria, profundamente arraigada en el pueblo colombiano, se constituía en uno de los fundamentos principales de esa unidad. En estos términos el Concordato fue el complemento necesario de la Constitución del 86. La unidad doctrinaria del catolicismo y su trayectoria como basamento cultural de la Nación; la amplitud y solidez del aparato burocrático de la Iglesia y la legitimidad y aceptación de su autoridad eran elementos indispensables para el proyecto político conservador. En esta perspectiva, la educación, "organizada y dirigida de conformidad con los dogmas y la moral de la Religión Católica," 10 cobraba todo su significado. Para la unidad política era necesaria la unidad ideológica y para ello, la Iglesia garantizaba la orientación católica de la educación y aportaba su aparato institucional, su organización, su estructura. Fue así como el conjunto de las funciones asignadas a la Iglesia tomaron cuerpo en los artículos 12 y 13 del Concordato.

Sin embargo, el Estado impuso su autoridad. Al explicar en que la suprema inspección de la educación y su sostenimiento quedaban por parte del gobierno y la Nación, lo cual fue adoptado por el Plan Zerda y la Reforma Uribe. De otro lado, la Ley Orgánica de 1903 avanzaba un paso más sobre el plan Zerda, mediante la reorganización del Ministerio de Instrucción Pública. Esta hizo una definición rigurosa de las funciones directivas y administrativas del ejecutivo. ${ }^{11}$ El papel asumido por el

\footnotetext{
8 JARAMILlO URIBE, Jaime. (1980): El proceso de la educación. Manual de Historia de Colombia. Tomo III. Colcultura, Bogotá, p. 280.

9 MELO, Jorge Orlando. (1978): La República Conservadora, en Colombia Hoy. Editorial Siglo XXI, Bogotá, p. 35.

10 Ibídem, p. 45

11 Decreto 491 de 1904. Capítulo 1.Artículos 1 al 5 de la Ley 39 de 1903, en Educación Colombiana p. 17 y ss.
} 
Estado en la educación pública era expresión de la tendencia hacia la centralización, tendencia que fue todavía más nítida en la promulgación de un Plan Nacional de Estudios para la primaria y la secundaria, y en la homogenización legal de principios pedagógicos relativos al sistema correccional y a las funciones de los exámenes y de los maestros. ${ }^{12}$ De esta manera, la reforma de Uribe hizo un esfuerzo para utilizar la educación como un medio que lograra la unidad ideológica de la Nación y afianzara por este camino, la presencia del poder central en la vida nacional. Ahora bien, la Ley Orgánica no contempló la educación solamente como una palanca, por lo demás formidable para estimular la unificación espiritual de la Nación y forzar la centralización del poder, sino que también le señaló un papel sobresaliente en el campo de la economía.

En efecto, en las últimas décadas del siglo XIX, específicamente a partir de la guerra de 1876, el país comenzó a dar con escasos éxitos pero con halagadoras perspectivas, los primeros pasos en la industrialización. ${ }^{13}$ El desarrollo de la minería sobre bases técnicas estimuló el surgimiento de pequeñas fábricas que generaban mercados urbanos; el crecimiento de la banca y de la acumulación de capital comercial, complementaban el esfuerzo al atender solícitamente los requerimientos del capital productivo. El triunfo de Núñez y de la política proteccionista alimentó la esperanza de los empresarios fabriles, y a pesar de la ambigüedad de las medidas económicas tomadas por la Regeneración y de la inestabilidad política, fue "posible advertir que a partir de 1890 aumenta el interés por el establecimiento de industrias modernas sobre todo en Antioquia." ${ }^{14}$ Por otro lado, la economía cafetera venía desarrollándose lenta pero constantemente desde 1870 . Entre 1887 y 1897 se sembraron cerca de 30 millones de árboles solamente en la zona oriental, y se incrementaron las exportaciones de café a una tasa promedio del 18.5 por ciento, ${ }^{15}$ la exportación pasó de 106.431 a 510.179 sacos. Para 1885-90 los ingresos provenientes de este renglón generaron cuatro millones de pesos, casi el doble de lo que representó el tabaco en su mejor época (de 1866 a 1869). ${ }^{16}$

En estos términos, al finalizar el siglo XIX la economía del país exhibía síntomas alentadores de un crecimiento fundado sobre bases sólidas y con perspectivas nuevas, que no lograron demoler ni oscurecer la sucesión de guerras civiles ocurridas en las tres últimas décadas de ese siglo. El propósito de contribuir por medio de la educación a enfatizar la tendencia de desarrollo, estimular el crecimiento de la economía y recuperar el ritmo perdido con ocasión de la Guerra de los Mil Días, está claramente expuesto en la reforma de Uribe.

\footnotetext{
12 Decreto 491 capítulos IX, XI y XII.

${ }_{13}$ MELO, Jorge Orlando. (1978): La evolución económica de Colombia 1830-1900. Manual

de Historia de Colombia. Tomo III. Colcultura, Bogotá. Pág. 204.

${ }^{14}$ Ibídem, p. 204.

${ }_{15}$ MACHADO, Absalón. (1977): El café: De la aparcería al capitalismo. Editorial Punta de Lanza. Bogotá, p. 33.

${ }^{16}$ KALMANOVITZ, Salomón. (1978): El régimen agrario durante el siglo XIX. Manual de Historia de Colombia. Tomo II. Colcultura, Bogotá, p. 307.
} 
Aparecen en primer lugar dos innovaciones frente al plan Zerda: la diferencia, aunque todavía vaga, entre la instrucción profesional y la instrucción industrial, y la división de la secundaria en técnica y clásica. La distinción entre lo técnico y lo clásico, entre lo industrial y lo profesional, y la concordancia entre lo técnico y lo industrial, lo clásico y lo profesional apuntan, sin lugar a dudas, a esbozar un programa de educación técnica divorciado del esquema tradicional heredado de la Colonia. En segundo lugar, el estatuto de Uribe subraya de manera persistente los objetivos económicos de la educación aunque sin detrimento de los objetivos morales. La enseñanza debía habilitar a los educandos para el ejercicio de la ciudadanía, de la agricultura, de la industria fabril y del comercio. ${ }^{17}$ Las escuelas normales debían formar maestros idóneos para transmitir a sus alumnos nociones suficientes no sólo en el orden moral e intelectual, sino también principios aplicables en la industria, la agricultura y el comercio. ${ }^{18}$ Por medio del Artículo 16 de la Ley de 1903, las Asambleas Departamentales quedaron facultadas para establecer "escuelas de artes y oficios que enseñen artes manufactureras y especialmente el manejo de máquinas aplicables a las pequeñas industrias"19 - El Instituto Agrícola y la Escuela de Minas atenderían de "un modo científico la explotación de las riquezas naturales del país." ${ }^{20}$

En estos términos, la reforma de Uribe le atribuyó a la educación y también al sistema educativo una responsabilidad económica. Pero sobre todo, se destaca el propósito explícito de calificar técnicamente a todos los niveles la mano de obra que requería el desarrollo industrial. Quizás por este motivo la Ley Orgánica privilegió tan unilateralmente la escuela primaria urbana. Para los gobiernos conservadores posteriores a la Guerra de los Mil Días, la industrialización fue un proyecto que se quería dar en una opción real e inmediata. La reforma de Uribe, en este sentido, no fue más que la expresión de esa alternativa; la habilitación práctica de la fuerza de trabajo en el menor tiempo posible era el reto que debía afrontarse. "La clase empresarial y la burguesía nacional - -dice Jaramillo Uribe- que siempre había manifestado sus exigencias de una educación más práctica, adecuada a los nuevos proyectos económicos, siguió insistiendo en ellos bajo los gobiernos posteriores a la guerra. Desde el punto de vista legislativo y la Ley Orgánica respondió a esa exigencia.”21

\section{Maestros de Escuela}

A mitad de la primera década del siglo XX, y no obstante el reconocido celo en favor de la difusión y desarrollo de la Instrucción pública primaria, y siguiendo las instrucciones expresadas por el Sr. Rafael Reyes, Presidente de la República, se solicitaba a los Departamentos incluir en los Presupuestos, las partidas necesarias para dotar de una manera suficiente el sueldo de los Maestros de escuela y velar porque el pago se

\footnotetext{
17 LEY 39 DE 1903, artículo 6º, 15,16.

18 Ibídem, Art. 15.

19 Ibídem, Art. 16.

${ }^{20}$ Ibídem, Art, 20.

${ }^{21}$ JARAMILLO URIBE. Op. Cit, p. 40.
} 
hiciera con la mayor puntualidad posible, toda vez que la figura del maestro era tomada como abnegada y sumisa (abnegados ciudadanos), ${ }^{22}$ tanto que no tenían otro elemento de vida sino el escaso sueldo que ganaban; de tal manera, que se llamaba la atención de que si no se les cubría el salario, éstos se verían obligados a abandonar la escuela para buscar otro trabajo que les permitiera atender las necesidades de la vida. Así mismo, se decía como al Ministerio de Instrucción Pública llegaban constantes quejas de Maestros de Escuela a quienes se les debían sueldos de meses y aún de años. Se planteaba que era necesario dar instrucciones terminantes a los empleados pagadores, a fin de que cubrieran preferentemente los sueldos de los Maestros de Escuela y dictaran las providencias necesarias para que estos pudieran recibir tales sueldos con las mayores facilidades posible, que ojalá fuera en las mismas escuelas que regentaban, con el fin de evitar inútiles gastos de traslación y tener que abandonar las tareas escolares. Se le solicitaba a la Gobernación y a la instrucción pública vigilaran con el mayor interés a los Municipios para que pagaran con puntualidad tales sueldos, y, si fuera posible, que se destinará especialmente para tal objeto algunas rentas municipales ya creadas o que en lo sucesivo pudieran crearse. Aunque en muchos Municipios la Instrucción Pública tenía capitales propios estos no eran manejados con acuciosidad y por lo tanto eran insuficientes para atender el servicio para el que estaban dedicados. Se insistía desde el Ministerio dictar medidas eficaces para que a la mayor brevedad produjeran un justo rendimiento. De igual manera, se hacía un llamado a reivindicar, sin contemplación de ninguna clase, las propiedades pertenecientes a la Instrucción pública, que por uno u otro motivo, estaban en manos de particulares. ${ }^{23}$

Para los Departamentos y Municipios cuyas rentas no alcanzaban a cubrir los gastos de Instrucción pública, le correspondía al Sr. Gobernador y al Sr. Director de Instrucción Pública crear nuevas rentas o imponer contribuciones sobre la industria que, como la de fabricación y expendio de la chicha, afectaba no solamente la moralidad pública sino también el estado sanitario e higiénico de las poblaciones. Se recomendaba el nombramiento de Inspectores Escolares idóneos, activos, laboriosos y amantes de la Instrucción, que visitaran constantemente las escuelas y que obligaran a los Municipios a pagar puntualmente los sueldos de los Maestros de su cargo.

Se insistía en la necesidad de difundir la instrucción primaria, a lo menos en su parte elemental, para toda la población, prestando especial cuidado a la fundación de escuelas rurales, especialmente donde hubiera tres casas vecinas. Para lograr los resultados esperados, era menester y obligatorio ponerse en contacto con los Sres. Párrocos de los Municipios, a quienes los Directores de Instrucción Pública debían suplicarle para que promovieran, a través del pulpito, la concurrencia a las escuelas públicas, en las cuales ellos mismos debían dictar la clase de religión. Que el clero, por su índole misma de su sagrada misión, era y había sido siempre partidario del movimiento Instruccionista. Se daban ejemplos de muchos sacerdotes que habían organizado en

${ }^{22}$ REPÚBLICA DE COLOMBIA. Ministerio de Instrucción Pública - Sección $1^{\mathrm{a}}$ - Ramo

de Negocios generales - Bogotá, Julio 4 de 1905. Circular número 1025.

${ }^{23}$ Ibídem, circular 1025. 
sus respectivas parroquias la enseñanza primaria rural con carácter ambulante, como lo había hecho el virtuoso y emprendedor Dr. Pedro Pardo, Cura de Pesca, quien en cada una de las pobladas veredas de su parroquia había organizado la enseñanza elemental dos veces por semana. ${ }^{24}$

Muchas veces se reiteraba por parte del Ministerio de Instrucción pública el deseo de no omitir esfuerzos para dar a la instrucción primaria todo el desarrollo que debía tener, difundiéndola tan extensamente como fuera posible, puesto que una de las necesidades más imperiosas de la República era la de levantar la condición de las masas campesinas y rurales; las cuales estaban sumidas en la mayor ignorancia. Recalcando que inmensa era la diferencia que había entre el individuo que sabía leer, escribir y contar, y aquel que ignoraba estas nociones elementales, cuyo conocimiento dignificaba al hombre y lo transformaba. Que con la transformación individual se obtendría la benéfica transformación que haría de Colombia un país digno, rico y laborioso. ${ }^{25}$ En medio de este auge por la educación elemental, se dieron sanos propósitos para fomentar las buenas costumbres, inculcar hábitos de moralidad, benevolencia e inculcar en el corazón de los niños sentimientos de caridad. Pero a estas buenas intenciones del gobierno se le oponían serios obstáculos, tales como la inercia de los padres de familia por no llevar los niños a la escuela, la marcada pobreza de las regiones, la falta de caminos de acceso a las poblaciones, las distancias que debían recorrer los niños para llegar a las escuelas, entre otras.

Se decía que en los niños estaba las semillas para cultivar el porvenir de la patria. Por lo tanto, era la escuela donde se debían corregir los errores adquiridos en la familia, fomentar las buenas inclinaciones y atender cuidadosamente el carácter de los niños. Aunque se sabía que el carácter no se cambiaba por completo, se insistía que se debía modificar favorablemente con las prácticas religiosas, la educación social y la contemplación de la naturaleza. Que el niño aprendiera a conocer muchas de las cosas que veía constantemente, y se le abriera nuevos horizontes a su inteligencia para crear nuevos sentimientos en su corazón, donde aprendieran a proteger y amar las obras de Hacedor Supremo. No menos importante era inculcar en los niños los sentimiento de benevolencia hacia los animales, y principalmente, hacia las aves, combatiendo, por cuanto medio fuera posible, el cruel instinto de destruirlas y ahuyentarlas. Esta costumbre popular la debería borrar la escuela. ${ }^{26}$ En respuesta a las directrices del Ministerio, en los informes que rendían a la Dirección General de Instrucción Pública, los Directores departamentales mostraban un interés por cumplir fielmente cada uno de los lineamientos generados por el gobierno central. El Distrito Capital, bajo la dirección del Dr. Gerardo

${ }^{24}$ UNIVERSIDAD PEDAGÓGICA Y TECNOLÓGICA DE COLOMBIA. Fondo pedagógico. Memorias de Instrucción pública. Revista de Instrucción pública, 1906.

25 REVISTA DE INSTRUCCIÓN PÚBLICA DE COLOMBIA. Periódico Oficial destinado al fomento y a la estadística de los establecimientos de enseñanza pública. (1905). Circular 1025. Bogotá: Imprenta nacional.

${ }^{26}$ REVISTA DE INSTRUCCIÓN PÚBLICA DE COLOMBIA. Periódico Oficial destinado al fomento y a la estadística de los establecimientos de enseñanza pública. (1905). Circular 1135. Bogotá: Imprenta nacional. 
Arrubla, manifestaba que el Consejo Administrativo del Distrito había apropiado las partidas necesarias para que el servicio escolar fuera atendido de modo preferente y que no omitiría esfuerzo para lograr un Decreto de aumento en los exiguos salarios de los maestros, y así mismo velaría para que el pago se hiciera puntualmente. Así mismo, pondría esa Dirección empeño en aumentar el número de escuelas y levantar el nivel intelectual del maestro por medio de estímulos eficaces. Se hizo un Decreto, por el cual se establecía que las vacantes en el personal de maestros se llenaban por el sistema de concursos de oposición. En el Distrito los Sres. Sacerdotes, como los inspectores locales natos, tenían injerencia directa en la marcha de las escuelas. ${ }^{27}$

Los demás Departamentos del país asumían las orientaciones que se daban a la instrucción pública nacional promoviéndola y aplaudiendo el pensamiento del Ministro de Instrucción Pública Antonio José Uribe, desde el Gobierno de José Manuel Marroquín y los posteriores, por difundirla a través de la Revista de Instrucción Pública. La cual era leída en todas las escuelas de todos los Distritos, como medio de información del movimiento oficial del ramo y de los estudios o publicaciones importantes en que eran útiles para iniciar a los educandos desde los primeros años. ${ }^{28}$ Se reclamaba un esfuerzo, en todos y cada uno de los Departamentos, de abnegación y patriotismo para llevar a feliz término la obra de reconstrucción del país después de la Guerra de los Mil Días, y este reclamo iba dirigido especialmente a los conductores de la juventud, quienes eran los conductores de dirigir la sociedad futura. Estos debían extirpar los vicios que devoraban a la sociedad y formar ciudadanos virtuosos para el porvenir. Esta era la meta que la educación debía seguir con perseverancia, a fin de que los buenos principios se infiltraran en los corazones tiernos. ${ }^{29}$

Se hacía un llamado a utilizar las fábulas, anécdotas, ejemplos y proverbios, todos aplicados en su momento oportuno para que fueran gravados fácilmente y de los cuales podía el maestro elaborar sabias y útiles lecciones a sus discípulos. Eran, por tanto, la Urbanidad y la Moral las materias centrales sobre las cuales los maestros debían dictar sus lecciones, no perdiendo oportunidad alguna de enseñar, tanto con la palabra como con el ejemplo, el estricto cumplimiento de los deberes del hombre para con Dios, con la Patria, con la sociedad y consigo mismo.

Además, se prohibía entre los niños toda clase de negocio y juegos de apuestas, ya que eran gérmenes de la codicia, en cambio se debía fomentar el amor al trabajo, como

\footnotetext{
27 REPÚBLICA DE COLOMBIA. Consejo Administrativo. (1905). Bogotá. 10 de Julio de 1905 - número 21, en Revista de Instrucción Pública de Colombia. Periódico Oficial destinado al fomento y a la estadística de los establecimientos de enseñanza pública. (1905). Bogotá: Imprenta nacional.

${ }^{28}$ REPÚBLICA DE COLOMBIA. Departamento de Bolívar, Caldas, Cundinamarca. Dirección de Instrucción Pública del Departamento. Sección de Instrucción Pública. Número 104. Cartagena, 22 de julio de 1905; Caldas, Gobernación número 19; Facatativá, número 95. En: Revista de Instrucción Pública de Colombia. Periódico Oficial destinado al fomento y a la estadística de los establecimientos de enseñanza pública. (1905). Bogotá: Imprenta nacional.

${ }^{29}$ Ibídem, p. 52.
} 
única fuente lícita y segura de prosperidad e independencia. A la labor del Maestro debía la patria sus más bellos triunfos..$^{30}$ Por Decreto número 188 de 1905, el Gobierno nacional dispuso que los Directores de los Colegios y Escuelas de la República sacarán a los alumnos dos veces por semana a efectuar paseos a pie, con la libertad necesaria para que los niños pudieran practicar los ejercicios de carrera, salto y todos los que fueran útiles para el desarrollo físico y científico. Los paseos se hacían preferentemente en las horas de la mañana, durante un tiempo no mayor de tres horas; los días de paseo eran fijados por el Director de la Escuela, de acuerdo con el Inspector local, con el fin de buscar el día propicio: nublados para el clima cálido y despejados para el clima frio. Las excursiones se hacían por las haciendas y los campos con el fin de reconocer la agricultura de esa localidad, aprendiendo el clima, la época de siembra y de cosecha, operaciones mecánicas necesarias con el uso y ventajas de las máquinas. Cada Escuela llevaba un libro especial, en el cual se debían anotar los días, lugares y materias de cada excursión. ${ }^{31}$

Si bien se observa que hubo un interés de gobierno central por promover la educación elemental, también cabe reconocer que una buena parte de estas intenciones se quedaron en decretos, resoluciones y circulares. Dado que durante y después de la Guerra de los Mil Días, los locales de las escuelas fueron convertidos en cuarteles, sufrieron deterioros terribles, que hasta bien entrado el Siglo, no habían podido conseguir su reparación, a pesar de los muy laudables esfuerzos de los Gobiernos Departamentales como los Municipales. La nación se quedó a la saga para solucionar este problema y no prestó ningún auxilio a los Municipios, toda vez que el deterioro se debía al ejército nacional. ${ }^{32}$ Así mismo, se manifestaba la carencia absoluta de útiles de enseñanza en muchos Departamentos. Las escuelas suplían la falta de tiza con tierra blanca o cal; pero la falta de pizarras y gises, y la de papel y plumas, no les era posible suplirlas con nada. También se quejaban de la carencia de textos de lectura, y que si bien el conocimiento de las primeras letras podía el Maestro enseñarlo de cualquier manera, la lectura mecánica y la ideológica requerían un texto uniforme y suficiente para el número de alumnos. ${ }^{33}$

Los principios y prácticas para la enseñanza elemental fuera de los Departamentos, como las Intendencias y Comisarías correspondían a otra realidad muy distinta a los primeros. Los Directores de Escuela, junto con el Inspector de Instrucción Pública de las Intendencias, manifestaban la carencia absoluta de locales para abrir la escuela pública, lo que obligaba a los Padres Misioneros Directores dictar clases en una pieza

\footnotetext{
${ }^{30}$ Ibídem, p. 55.

31 REPÚBLICA DE COLOMBIA - Departamento de Cundinamarca - Dirección de Instrucción Pública - Circular número 2 - Facatativá, Julio 6 de 1905. En: Revista de Instrucción pública (1905).

${ }^{32}$ REVISTA DE INSTRUCCIÓN PÚBLICA DE COLOMBIA. Periódico Oficial destinado al fomento y a la estadística de los establecimientos de enseñanza pública.(1905) : "Informe del Director de Instrucción Pública del Departamento de Cundinamarca". Bogotá, Imprenta nacional.

${ }^{33}$ Ibídem, p. 60 .
} 
de la casa donde vivian, donde asistían unos pocos niños. Todo el mobiliario se reducía a unos bancos sacados en su mayoría de la iglesia. No se contaba con mesas para escribir ni tableros, además de la difícil situación económica de las familias, los niños llegaban a las escuelas con las manos en los bolsillos. Casi nadie contaba con libros de texto, escasamente los maestros contaban con uno, del cual sacaba los programas que suplirían la falta de libros para los niños. ${ }^{34}$

Se manifestaba, de igual manera, que en las Intendencias, la Instrucción primaria se encontraba en el estado más deplorable por inacción absoluta e indolencia de las autoridades por este ramo, además de la miseria que rondaba estos territorios; "a causa de este abandono no había escuelas, ni casa municipal, cural, sin cárceles y sin nada" 35 . Muchos municipios carecían de escuelas, ni tampoco tenía muchas esperanzas que se abriera alguna por parte de las autoridades del lugar.

Manifestaba el Fray Nicolás, obispo de Adrianópolis:

A la vista de cuadro tan triste y tan desconsolador, ;oh! Eso es capaz de helar el entusiasmo más ardoroso y de dar lugar a que se crucen de brazos el hombre más decidido por la enseñanza. Ante la inmovilidad de peñasco de unos, ante la resistencia inmensa de inercia moral por parte de otros, por falta de punto de apoyo en el vacio de estúpida indolencia de los más de los padres de familia, ¿qué podrán valer brazos y esfuerzos? ¿De qué servirán entusiasmos $y$ voces de aliento? ${ }^{36}$

Los nombramientos de los Maestros y Maestras seglares se hacían por sus aptitudes y moralidad, colocándolos en pueblos, vecindarios y aún haciendas de hatos donde fuera posible. Sin embargo, el apoyo del Ministerio no fue el mejor en cuanto a las solicitudes de libros y útiles escolares que se hacían desde las Intendencias. En respuesta enviaban una caja con una porción de tubos de vacuna, dos arrobas de semilla de algodón, con un folleto titulado el ABC para el cultivo del algodón. ${ }^{37}$ Algunas de las funciones que debían cumplir los Inspectores de Instrucción Pública era la de disponer que los municipios apropiaran locales adecuados para las escuelas, y los proveyeran de los muebles necesarios; así como también, que en todas las escuelas se observaran estrictamente las medidas de higiene prescritas por la Junta Central. En orden a esto, dadas las misiones en las intendencias, se decía que en un pueblo católico después de la iglesia, el mejor edificio que debería haber era una buena escuela, por ser un sitio casi sacro, donde se formaba el hombre para el servicio y la honra de la religión, la familia y la patria.

\footnotetext{
${ }^{34}$ Intendencia del Meta. (1905): Informe del Vicario Apostólico del Casanare, inspector de Instrucción Pública en las escuelas de ese territorio de la Intendencia del Meta, en el primer semestre del año.

35 Ibídem, p. 75.

36 Ibídem, p. 75.

${ }^{37}$ Ibídem, p. 73.
} 
En conformidad con estas ideas, y particularmente con las de formar cristianamente el corazón de la niñez, inculcándole de un modo objetivo el amor a la religión y a la veneración y el respeto que todo hombre debía tener, sobre todo el católico, a las supremas autoridades del mundo y de la Nación en su respectiva esfera de orden espiritual y temporal, se hicieron colocar en todas las escuelas tres imágenes o retratos: uno, de Jesucristo Nuestro Señor crucificado, sabiduría increada, fuente y principio de toda verdad y ciencia; otro, a la derecha de su Vicario augusto en la tierra, Nuestro Santísimo Padre el Papa, y el otro, a la izquierda, del Jefe Supremo de la Nación, autoridad primera de ella en el orden temporal. ${ }^{38}$ A falta de útiles, la gestión de imágenes religiosa cumplía su labor.

Así mismo, los Inspectores procuraban que la educación en las escuelas fomentara la enseñanza y la educación en la niñez, señalando las materias principales que, atendiendo a las circunstancias de los pueblos, deberían enseñarse de preferencia y por mayor necesidad, como fueron: el catecismo (Religión y moral), explicado con mayor o menor amplitud según la edad y el estado de instrucción de los niños; leer, escribiry contar, con la mayor perfección que se podía en cada año o curso escolar, añadiendo poco a poco materias prácticas de acuerdo con el nivel del niño. De estas materias se preferían las de enseñanza de la pequeña industria manual, cultivo de plantas que produjeran materias primas, agricultura, oficios manuales, ganadería y cría de animales.

El propósito fundamental de la enseñanza primaria fue formar verdaderos ciudadanos, católicos verdaderos de obra y de práctica, hombres honrados y útiles al pueblo y a la sociedad. De aquí la enseñanza del catecismo como base para la instrucción y para luego formar hombres de trabajo, de industrias, buenos artesanos y obreros inteligentes aficionados a la vida de labor del taller y del campo. Esto implicaba dejar de lado la literatura y los conocimientos vagos, que como por ser efimeros e inconexos ningún provecho les podría traer. ${ }^{39}$ En cuanto a los niños indígenas o semiindios, fueron abiertas escuelas superiores, o colegios, tanto para niñas al cuidado especial de las Hermanas de la Caridad, como para niños bajo la dirección de los Hermanos de la Cristianos. ${ }^{40}$

Finalmente, los Padres Misioneros, junto con todas las órdenes religiosas, siempre proclamaron su voluntad de coadyuvar, cuan eficazmente podían, a la obra salvadora del Gobierno de Colombia, único en el mundo, que tenía la gloria y el valor cristiano de tener puesta en manos de la Iglesia la enseñanza escolar y profesional, según lo proclamaba abiertamente en los artículos 11, 12,13 y 14 del Concordato y en otros documentos públicos, haciendo cuanto de su parte estuviera en servicio de la educación científica, literaria, moral, artística, industrial y comercial de los pueblos. Así mismo, se decía que con autoridades decididas, celosas y enérgicas para hacer cumplir debidamente las órdenes del Ministerio en relación con escuelas, muebles y otras cosas

\footnotetext{
${ }^{38}$ Ibídem, p. 77.

39 Ibídem, p. 78.

40 Ibídem, p. 79.
} 
más, se podía esperar que un soplo de vida recorriera aquellas cordilleras y llanos, resucitando en cierto modo aquellas pobres sociedades humanas que parecían estar aletargadas, adormecidas y medio muertas. ${ }^{41}$

\section{El ideal del maestro cristiano}

Para las tres primeras décadas del siglo XX, la escuela es una creación y una redención. Se pensaba que la educación consistía en excitar y dirigir la actividad libre del hombre para que adquiriera toda la perfección en consonancia con su naturaleza; era la dilatación del ánimo hasta llegar al ideal natural y sobrenatural, como fin para el cual Dios lo había creado y puesto en este mundo. Así educar un niño era devolverle los dones que había recibido del cielo; era formar el hombre, el ciudadano y el cristiano: hombre con dignidad, ciudadano con intenso amor patrio y cristiano a carta cabal. ${ }^{42}$ Múltiples eran los medios para conseguirlo y numerosos los libros para enseñarlo, pero la base para lograrlo estaba en el ideal de maestro que formaba los niños del país. Se imaginaban espacios donde la actividad del maestro generaba admiración, rodeado de sus educandos y ejerciendo con ellos el apostolado de la educación y la instrucción. El buen maestro debía ejercer celo en sus arduas tareas; en sus ojos debía brillar el amor que tenia por esta obra de vital importancia para la Patria; en su rostro mostrar suavidad, y por la postura del cuerpo hacer comprender la importancia de la magisterio que ejercía. Se comparaba al maestro con el genio que buscaba realizar una obra comprendida en la mente y sentida en el corazón. Así mismo, el maestro cristiano, iluminado por una luz superior, enardecido por el fuego del amor patrio, levantándose de deseo en deseo, debía concebir una clara idea de la Divinidad, adorar la belleza creada y desbordase en purísimo gozo frente al Creador. Así, los maestros debían formar hombres cuya educación física, moral e intelectual no solo les fuera útil para la familia, el individuo y la patria, sino para la consecución de sus destinos inmortales. El magisterio era sacerdocio sublime, cuyo ejemplo estaba dado por el Maestro Divino, Nuestro Señor Jesucristo. ${ }^{43}$

El maestro fue comparado con el apóstol, por lo atrevido de la doctrina que anunciaba; con el mártir, por el heroísmo de sus acciones; con el pontífice, por ser padre de los pueblos; con el doctor, por brillar con los esplendores de la ciencia y con la Virgen, por expresar poesía. El buen maestro debía encerrar todas estas cualidades. Por lo tanto, el lugar donde habitaba él, se convertiría en un germen de todo bien, un sitio que tomaba prestados los rasgos del templo y se asemejaba al hogar paterno; siendo la prolongación de ambos. La escuela era el laboratorio de la naturaleza humana, que daba remate a los pinitos empezados en el hogar. El joven no era sino un esbozo, un hombre en flor; llevaba consigo tesoros escondidos, potencias adormecidas, que convenían desenvolver y poner en juego la actividad de la que eran capaces. La cabeza

\footnotetext{
41 Ibídem, pp. 83 al 86.

${ }^{42}$ HERMANO GONZAGA, Luís. (1913): "Discurso pronunciado en la distribución de premios de la Escuela Normal Central de Institutores de Bogotá el 29 de noviembre de 1913", en Revista la de Instrucción Pública de Colombia. Órgano del Ministerio del Ramo. Tomo XXVI. Bogotá, enero y febrero de 1913. Números 1y 2.

${ }^{43}$ Ibídem, p. 773.
} 
podía aun semejar la de un querubín, que servía de escabel a los pies del Altísimo; ${ }^{44} \mathrm{el}$ pensamiento estaba sembrado en la facultad, no tardaría en aparecer, posible era que se remontara hasta lo sublime y que sirviera de alas al genio; empero, era la escuela la que recibía ese relicario, allí el pensamiento juvenil se ponía en contacto con los objetos reales; el educando aprendía allí a conocer, antes de saber nombrar lo que veía y lo que palpaba. La palabra nacía del conocimiento; en el hogar se desataban los cordones del lenguaje; el amor materno enseñaba las palabras sagradas; en la escuela se dirigía ese verbo novel hasta las cumbres de las reglas gramaticales, para que después subiera, si fuera posible, hasta la cúspide del arte literario. Cuando el pensamiento encontraba la palabra, el educando estaba en la posibilidad de adelantar en la carrera empezada y trazaba el surco de su grandeza o de su miseria. ${ }^{45} \mathrm{El}$ educando no era pura inteligencia: en él la vida palpita bajo el músculo; le tocaba al educador desarrollarla armónicamente, por mínima que pudiera haber sido; cultivaba esas fuerzas por medio de la educación física; con ejercicios combinados, dejándoles algunas veces la espontaneidad para que los educandos las disfrutaran. Se formaban esos músculos de acero y esos puños de hierro, porque ello hacía circular la sangre generosa, cuya virtud era la fuerza y valor que formaba los soldados de la Patria, en la hora del peligro y en los momentos de angustia. ${ }^{46}$

Después del pensamiento y del órgano que servía para la expresión, se presentaba el alma, como centro a donde iban a parar las sensaciones de los sentidos externos. El educador los debía cultivar y educar, dándoles cuidados adecuados para que contribuyeran a la formación del hombre por medio de la disciplina racional; así le enseñaban el respeto de la autoridad a quien representaba; combatían los caprichos, ponían un muro a la turbulencia y castigaban la rebeldía. De la lucha entre la naturaleza y la ley; cuando esta lograba la primacía, resultaba el carácter recto, honesto y valeroso, que sería el honor de la Patria. ${ }^{47}$ Seguido este rumbo, si no había contratiempos, los caracteres se templaban y la Patria cosechaba óptimos frutos. Un maestro podía considerar su carrera con satisfacción, ni exigía el aplauso de la opinión, porque ello desvirtuaría el merito adquirido; derecho tenía para pensar que ejecutaba grandes cosas y estar convenido de ello para encontrar el valor necesario para tan ardua tarea y no descorazonarse en los contratiempos.

Si la escuela era el laboratorio de la naturaleza humana, también lo era de la gracia: "dicho está que el hombre es un dios caído que se acuerda de la patria celestial". El educando, a pesar de los encantos que lo embalsamaban, era una ruina en donde fácilmente se podían encontrar las huellas del pecado a través del fulgor, de la mansedumbre, de la sonrisa y de la limpidez de la mirada. La escuela podía hacer del joven un sabio, pero no formaba un hombre a carta cabal: quien pensara lo contrario erraba. El niño heredaba las consecuencias del pecado original: la ignorancia, la sensualidad y el orgullo. La educación bien dirigida podía curar esas llagas, con amor

\footnotetext{
44 Ibídem, p. 774.

45 Ibídem, p. 772.

46 Ibídem, p. 743

47 Ibídem, p. 745.
} 
y con respeto podía el educador ofrecer el pan de la verdad: sin dudar que las artes, ciencias y letras simbolizaban la cultura en sumo grado, pero que la enseñanza cristiana encerraba la solución a todos los grandes problemas que iluminaban las tinieblas de lo pasado, de lo presente y lo futuro. ${ }^{48}$

Con acción simultánea podía el educador derramar en los educandos dos luces, emanadas de un mismo foco: ciencia y de fe, que a Dios gracias, no había antagonismo entre ellas, sino que más bien, se apoyaban mutuamente, con ellas la noche de la ignorancia se disipaba como las tinieblas. La sensualidad que bullía en los corazones juveniles y también dormía con ellos, como la lava en las entrañas de los volcanes: ${ }^{49}$ basta algunos grados de calor para que saliera a modo de torrente devastador; esta fatal herencia era de las más funestas consecuencias que la ignorancia, era una negación y causa del mal. Los vicios, que si no eran cohibidos, subían hasta las regiones sagradas del alma y la empañaban con los desgastes que le ocasionaban, sumiéndola en los antros de la ignominia y la deshonra. Ante estos peligros el educador, si era digno del nombre que lleva, podía promediar el mal, desenvolviendo ante los ojos del educando para precaverlo contra las tempestades del mañana, La belleza moral era el esplendor de la verdad; la belleza en todas sus formas, en la magnificencia de la naturaleza, en la armonía de los elementos, en las bellezas del arte, cuyos anales recorrían en las páginas de la historia; la belleza en la literatura, que era la gloria más delicada de espíritu humano, aroma que todos los pueblos guardaban con exquisito cuidado; empero, ¿quién no se deja cautivar por la belleza moral, imagen de la belleza moral, imagen de la belleza de Dios? ¿Quién resistiría esas enseñanzas si ellas están apoyadas con el ejemplo palpitante de la vida correcta del educador? $?^{50}$

En el Evangelio estaban las lecciones más eficaces, porque este libro era el código de todas las magnificencias morales; sus enseñanzas eran barreras de toda concupiscencia, sanción de todo desarreglo. También hallaban ejemplos en la historia pagana, ${ }^{51}$ pero los más provechosos eran los que brindaban los anales del Cristianismo, en donde palpitaba el triunfo en heroicos combates, ya de los mártires, ora de los intrépidos confesores y de las gloriosas vírgenes. El maestro debía entender el orgullo del educando como el gran enemigo de Dios y de los hombres. La buena educación podía desbaratar las argucias del demonio, porque ella vigilaba sus movimientos, espiaba

\footnotetext{
${ }^{48}$ Ibídem, p. 746.

${ }^{49}$ Ibídem, p. 736.

50 Ibídem, p. 740.

${ }^{51}$ Conviene definir lo que significa la palabra paganismo: paganismo y pagano son palabras que provienen del latín "paganus" que era el término que designaba a una persona que residía en el campo o simplemente campesino. Es una referencia a una época en que los cultos urbanos del imperio se establecían como religión oficial, dándole así un carácter de élite a la espiritualidad del imperio, mientras que las personas del campo continuaban con los viejos ritos. Los cristianos urbanos de Roma utilizaban este término de forma peyorativa haciendo alusión a las religiones de los campesinos, lo cual hizo que con el tiempo adquiriese un nuevo significado, es decir "hombre sin Dios", ya que de acuerdo con el criterio cristiano de aquella época su religión era la única religión valedera.
} 
todas sus manifestaciones y daba al traste con las turbulencias que este ser ponía en los corazones de los niños. Para calmarlo se hacían consideraciones eficaces, como el castigo físico, la justicia y la firmeza, que era la vara de hierro envuelta en terciopelo. Dirigida así una casa de educación se convertía en un templo; el empleo de maestro se levantaba a las alturas del sacerdocio; entonces la educación fructificaba, y sus frutos eran el hombre injertado en el cristiano; fruto digno de la palabra y sangre de Cristo; en el bautismo el hombre era llevado con el agua redentora, y la Eucaristía le sirvió de alimento; fortalecido con los motivos de credibilidad, su fe era razonable; por eso era mirado con sorpresa por los que eran incapaces de comprenderlo. ${ }^{52}$ Esta metamorfosis era el efecto de la gracia, que podía mejorar las consecuencias del pecado original, purificar las manchas y completar lo que falta a la obra de la naturaleza. Por eso la buena escuela no solo era creación sino redención.

De la escuela debía salir las vidas útiles, los talentos con orientación firme, los corazones generosos, los padres honrados, los obreros modelos, los ciudadanos sumisos, los magistrados puros, los artistas inspirados y los soldados intrépidos; de ella sacaban los medios de engrandecimiento. Cuando en ese recinto sacro se falseaban estas nociones, entonces, o era instrumento de bienaventuranza, sino móvil de decadencia y ruina. Los elementos de una buena educación eran: Dios, los padres, el maestro, el condiscípulo y el educando. El primero esclarecía la inteligencia y por lo tanto era horroroso pensar cuando en las escuelas era arrancado el Crucifijo, cuya sola vista podía consolar, sostener y fortificar, y con él desaparecían todas las enseñanzas cristianas. Se decía que el crimen aumentaba y que las naciones como Francia se habían criminalizado por haber arrancado al Salvador de sus escuelas, lo que llevaba a tener franceses que no amaban su patria y antimilitaristas. Lo anterior, todo como fruto de la escuela Laica. Se insistía a los padres usar más la autoridad que los sentimientos, pues esta perduraba, los otros no. El buen maestro debía cumplir con unas condiciones de moral muy elevadas, dando ejemplo como lo dio Jesucristo, sembrando ideas y haciendo aceptar principios con convicciones profundas desde el orden físico, intelectual y moral. ${ }^{53}$

Para desempeñar bien las funciones el profesor necesitaba salud vigorosa, rectitud y tacto acrecentados por el ejercicio perseverante y metódico, reflexión, observación, amor al estudio y gusto por la enseñanza; unido a lo anterior: dignidad exterior, reserva en las miradas, gravedad en el andar, serenidad de ánimo, bondad, urbanidad, nada en el lenguaje que pudiera ser considerado como grosero, lealtad y franqueza, honradez, buen humor para hacer de la escuela una mansión de la alegría. Pero se concluía que los mejores profesores eran los que comunicaban a sus discípulos el deseo y los medios de aprender para llegar más rápido a la divinidad. Es decir el maestro debía asemejar al maestro de maestro: Jesús

\footnotetext{
52 Ibídem, p. 737.

53 Ibídem, p. 738.
} 


\section{Escuelas primarias nacionales $^{54}$}

Las escuelas primaria, por razón del lugar donde funcionaban, se dividieron en urbanas y rurales; tanto las unas como las otras pudieron ser mixtas o de un solo sexo. En razón a la enseñanza se dividieron en elementales y superiores. Se establecía que en cada Municipio hubiera más de dos escuelas urbanas, por lo menos: una de varones y otra de niñas y las rurales que fueran necesarias según la extensión y población de las fracciones o veredas. En los Municipios donde el número, tanto de niñas como de niños, no pasaba de 25, podían las escuelas fundirse en una sola. Las escuelas primarias podían ser dirigidas por maestros idóneos, y en lo posible graduados, que reunieran las condiciones de ilustración, buena conducta moral pública y privada y que por lo menos gozaran de buena reputación en la sociedad. Los maestros de escuela debían ser del mismo sexo que los educandos. Con todo, las escuelas elementales de varones podían ser confiadas a señoras o señoritas que reunieran las condiciones anteriormente mencionadas; siempre y cuando a dichas escuelas no fueran niños mayores de doce años. Las escuelas alternadas siempre debían ser dirigidas por Señoras o Señoritas. Las escuelas siempre eran divididas en el menor número posible de secciones, a fin de que el maestro pudiera atender debidamente a la enseñanza y disciplina de todos y cada uno de sus educandos, y en ningún caso pasaría de tres si la escuela estaba dirigida por una sola persona. Estas tres secciones se denominaron: elemental, media y superior. ${ }^{55} \mathrm{La}$ duración del curso sería de dos años para cada una de las secciones. El número de trabajo diario en toda la escuela, cualquiera fuera el número de secciones que constara, sería de siete, las cuales se distribuían de acuerdo con el territorio y el clima del mismo, por ejemplo para el Departamento del Huila, el tiempo se distribuyo de siete a diez de la mañana y de doce a cuatro de la tarde. ${ }^{56}$ En cada una de estas secciones del día había media hora de recreo, a la hora que el Maestro determinara según su criterio.

Los maestros debían estar en la escuela media hora antes de empezar las clases, con el fin de verificar que los niños prepararan sus tareas. Cada clase duraba veinte minutos; sin embargo, en las secciones media y superior podían extenderse hasta treinta, según lo exigiera la importancia de la materia y el grado de adelanto de los educandos. Mientras el maestro estaba dando la clase a una sección, las restantes debían estar ocupadas con una tarea sobre la materia que iba a ser objeto de la próxima clase.

\section{Tácticas escolares}

El primer día de clase era el más importante para todos los niños en la escuela, por lo tanto los maestros debían asegurarse en dejar buena impresión: infundiéndoles amor

\footnotetext{
54 REPÚBLICA DE COLOMBIA. Ministerio de Instrucción Pública. Ley 39 de 1903. Decreto Reglamentario 491 de 1904. Decreto número 267 de 1912. Resolución número 134 de 1906, por la cual se aprueba un Decreto 87 de 1906, 11 de septiembre. En: Revista de la Instrucción Pública de Colombia. Tomo XX. Número 12. Bogotá, Diciembre de 1906.

${ }^{55}$ Ibídem, p. 662.

${ }^{56}$ Ibídem, p. 662.
} 
a la escuela, cuidando de decorarla con objetos arreglados simétricamente, el local aseado y los útiles de enseñanza preparados para usarlos, usando expresiones afables con cada alumno, imponiendo la disciplina y el orden desde el primer día, no consintiendo tumultos ni demostraciones de descortesía, diciéndoles que sería satisfactorio sacarlos del estado de ignorancia y hacerlos hombres útiles a la sociedad. Los ejercicios de entrada en cada día debían ser breves, apropiados, útiles e interesantes, los principales eran los siguientes: Lista, se sugería que cada niño tuviera su número de acuerdo con la lista nominal, por orden alfabético. El maestro iría anotando en el respectivo registro los que dejaban de contestar o de dar su número, con una rayita horizontal en la sección de la mañana y una vertical que corte a la primera en la sección de la tarde, si faltaba en ambas, cuando la falta le fuera excusada le agregaría un punto al signo indicado. Oración. Se daba principio a las tareas invocando el auxilio divino con las oraciones del Padrenuestro y Avemaría, o bien con un himno apropiado, seguidos de esta petición: Tono de la sabiduría, R: Ruega por nosotros. Al despedir a los niños se repetía el Avemaría, con una jaculatoria, dando gracias a Dios por los beneficios recibidos. ${ }^{57}$

El maestro hacía la clasificación de los alumnos para formar las secciones en que había de dividir la escuela con arreglo a los conocimientos que hubiera adquirido; para lo cual los sometía a una prueba que consistía en un ligero examen en aritmética y lectura. Estas dos asignaturas se tomaban como base para la clasificación, aun cuando en algunas otras tuvieran conocimientos más extensos por los cuales pudieran formarse en la sección inmediatamente superior o viceversa. Como no era a veces posible establecer una clasificación desde el principio permanente, el maestro la podía ir estableciendo a lo largo del curso, estudiando día a día las aptitudes de los discípulos para llegar a una clasificación adecuada. El maestro debía hacer la clasificación con imparcialidad y sin atender a exigencias extrañas. Cuando se encargaba de una escuela ya organizada por otro maestro, seguía la clasificación de su antecesor para no interrumpir el adelanto de algunos niños; a no ser que la encontrara muy defectuosa, pues en ese caso podía hacer las modificaciones que le sugiriera su juicio.

\section{Métodos de enseñanza en las Escuelas Primarias}

Los métodos de enseñanza que se aplicaron en la primaria fueron: el de Pestalozzi perfeccionado, intuitivo u objetivo; el socrático, interrogativo o erotemático; el acromático o de narración y descripción; el heurístico o deductivo; el genético o analítico, y el sintético, entre otros. ${ }^{58}$ Los métodos de enseñanza se aplicaron y pusieron en práctica según la materia. El método dependía del asunto, de la clase de alumnos y del maestro mismo. El objeto del método era el de instruir con facilidad, mediante el dominio de los asuntos que se enseñaban. Así el método de Pestalozzi, ${ }^{59}$ intuitivo u objetivo, era

\footnotetext{
57 Ibídem, p. 762.

58 Resolución número 134 de 19 de noviembre de 1906. Por la cual se aprueba el Decreto número 87 de 1906 para su aprobación enviado al despacho del Gobernador del Departamento del Huila y donde se reglamentan las escuelas primarias. Página 674

59 Ibídem, p, 674.
} 
apropiado en la enseñanza de la zoología, la botánica, la física, la escritura, la geografía, el dibujo y todo aquello que se pudiera representar o hacer sensible a los sentidos. Este método se llama objetivo porque con él se dan las lecciones con los objetos a la vista. El método socrático consistía pues en hacer hábiles preguntas al discípulo para conducirlo a descubrir la verdad por sí mismo. El maestro lo estimulaba y dirigía sin violencia, haciendo que él expusiera sus propias ideas; si éstas eran exactas, el maestro las fija por medio de oportunos ejemplos; si eran erróneas, le hacía ver claro el absurdo para que el discípulo descubriera sus consecuencias. Este método se recomendaba para desarrollar la inteligencia, pues se debía dejar al alumno todo el trabajo de observación é investigación, en el cual sintiera el goce del descubrimiento por sí mismo. Requería una atención sostenida y fuerzas intelectuales desarrolladas.

El método acromático empleaba narraciones, discursos y descripciones de las cosas. El nombre acromático venía de una voz griega que significaba oír para instruirse. Este método fue conveniente para enseñar historia, geografía descriptiva, moral, urbanidad composición, etc., pero había que tener mucho cuidado de no caer en el defecto y manía común entre los institutores, de adormecer a los niños con largas peroraciones y disertaciones fastidiosas, que narcotizaban la inteligencia y hacían caer al cuerpo en una especie de adormecimiento que enervaba hasta la vida. Para evitar esto se debía hablar poco e interrogar inmediatamente con viveza sobre lo enseñado, ó hacer que los niños escribieran un cuestionario o resumen de las lecciones. Este método se debía usar para enseñar á niños que tuvieran algún desarrollo intelectual y fueran capaces de entender el lenguaje del institutor. El método heurístico era el que empleaba el institutor para que los discípulos descubrieran por sí mismos las verdades, principios y reglas que deseaba enseñar, mediante ciertos datos suministrados para encaminarlos a hallar la verdad. Este método era sin duda el mejor de todos, porque lo que el niño descubriría nunca lo olvidaría, porque se consideraba como inventor o propietario de la cosa descubierta, además mantenía la imaginación en actitud provechosa para crear ideas, combinarlas y dar así al hombre la gran cualidad de observar, reflexionar y deducir lógicamente las verdades científicas: distintivos de sabios y filósofos. Este método debía usarse para enseñar gramática en cualquier idioma, aritmética, geometría, física, etc.; el institutor debía ser conocedor del plan que se proponía y tener la suficiente paciencia para esperar las respuestas del niño. ${ }^{60}$

El método genético consistía en combinar el método analítico con el sintético, que eran dos métodos auxiliares, es decir, se servían recíprocamente de ambos, según la materia que se tratara de enseñar. El análisis o método analítico consistía en tomar el todo para descomponerlo en sus partes, anotando las propiedades de cada una; era adecuado para el repaso de la gramática, la geografía, para enseñar fisiología, botánica, zoología. El sintético era aquel por el cual se procedía por las partes al todo, es decir, cuando se estudiaban las partes una a una para formar un todo armónico, y también cuando se procedía de lo simple a lo compuesto. Se utilizó para el dibujo de paisajes. Era absolutamente prohibido el método empírico o memorial, fundado en el ejercicio

\footnotetext{
${ }^{60}$ Ibídem, p 175.
} 
exclusivo y servil de la memoria. Esto no significaba que se excluyera el desarrollo de esta facultad en el niño, sino que se había de cultivar en combinación con el entendimiento, siguiendo el principio de Amos Conmenius, sabio gramático:"Nada, absolutamente nada debe aprenderse de memoria antes de haber sido perfectamente comprendido." En ningún caso, el maestro podía pasar de una parte de la lección a otra, antes de que los niños hubieran comprendido bien la parte o partes que se hubieran explicado. Los métodos generales expuestos, eran suficientes y los debían emplear los maestros. Pero además, se debía hacer uso de otros expedientes llamados métodos auxiliares pero que propiamente eran procedimientos. Habría conseguido su objetivo y merecía el dictado de institutor, el maestro que los empleaba con tino, que supiera alternarlos a tiempo y que hiciera uso constante de la repetición, cuya importancia se recomendaba.

Cualquiera que fuera el método adoptado se empleaba el procedimiento de muchos escritos, el tablero, la pizarra y el papel eran importantes auxiliares en la enseñanza y debían utilizárseles constantemente. También podía emplearse el procedimiento de ejercicios en coro, por toda la clase o por secciones de ella, para las respuestas, la lectura y las recitaciones. Estos ejercicios, empleados con moderación, servían para dominar la timidez, para acostumbrar al alumno a leer con pausas y con la entonación conveniente, y para fijar en la memoria un hecho cualquiera; pero cuando se empleaba de ordinario y casi con exclusión de otros medios, este procedimiento tenía un defecto de hacer que los alumnos abandonaran el estudio. Las respuestas en coro aparentaban mucho por la uniformidad mecánica, pero valían poco para la enseñanza sólida. No había que confundir el método con el procedimiento: el método en la enseñanza era el camino que seguía el espíritu para exponer y hacer comprender la verdad de lo que le enseñaban; el procedimiento era el medio práctico que empleaba el método para alcanzar su objetivo. Algunos ejemplos de métodos eran iniciar los estudios gramaticales dando una regla, explicita y confirmarla por medio de aplicaciones, era seguir un método. Principiar por hacer escribir varias frases, observar ciertas particularidades que le eran comunes y deducir una regla era seguir otro método. En ambos casos se procedía metódicamente. ${ }^{61}$

Ejemplos de procedimientos. Si para emplear los métodos indicados se servía de la lección que acababa de ser leída en el libro, ó se establecían ejercicios que los niños debían hacer por escrito, estos eran procedimientos. Leer una frase y hacer escribir en las pizarras palabras que por las relaciones entre sí guardaban, contenían la regla que se pretendía aplicar o retener, y después hacer presentar las pizarras y examinar si habían escrito bien o mal, es otro procedimiento. Valerse de una caja de letra para enseñar la lectura, de un tablero ó de un ábaco para enseñar a contar, es otro procedimiento.

Los procedimientos no valen sino por la inteligencia como se aplican. No se debe prescindir de ellos, pero no debe dárseles por si mismos una importancia exagerada.

${ }^{61}$ Ibídem, p. 176. 
Para que ejercieran influencia en los niños era menester que el maestro que los empleara comprendiera su razón de ser, que estuviera persuadido de ellos y que los practicara con gusto y naturalidad, pues de otro modo los alumnos, convertidos en autómatas, repetían pasivamente la lección, y esta llevaba el sello de la frialdad y carecía en absoluto de interés. Esto explicaba porque un procedimiento manejado por maestros que tenían conciencia de lo que ejecutaban daban prodigiosos resultados; y empleado por meros aficionados por virtud de servil imitación y solo en sus formas exteriores, engendraba la indiferencia y el hastió. Esto indicaba claramente que el maestro ilustrado que cumplía con interés sus deberes para con sus discípulos era el alma de los procedimientos, y que los resultados que obtenía en la escuela serían debidos a su instrucción y conocimientos pedagógicos. Si no era lícito exagerar la importancia de los conocimientos, tampoco sería razonable mirarlos con indiferencia. De nada serviría el maestro que tuviera la vocación para el ejercicio de su vocación y vehementes deseos de salir airoso en el manejo de la escuela, si ignoraba los procedimientos a que apelaban los prácticos en el arte de enseñar y educar. El que se dedicaba a maestro sin conocer los métodos y procedimientos admitidos por la pedagogía práctica moderna nunca alcanzaba el triunfo apetecido en la enseñanza. Se recomendaba pues a los maestros que sin haber hecho estudios especiales se encargaran de la delicada tarea de enseñar y educar, fueran muy estudiosos y procuraran tener consigo los tratados de los autores modernos sobre pedagogía y metodología, a fin de que sus conferencias se ajustaran en lo posible a sus doctrinas, pues de otro modo no podían ser satisfactorios los resultados de la escuela, por mas erudición que hubiera en el preceptor.

\section{Libros, registros e informes escolares}

Los libros, informes y registros eran de gran importancia por el auxilio que prestaban para el adelanto en las escuelas, y porque en ellos estaba fundada la estadística escolar. Tenían, entre otras, estas ventajas: $1^{\text {a }}$, servir de auxiliar al maestro en el mejor cumplimiento de sus deberes, por cuanto en ellos debía aparecer el estado de la escuela y era natural que el maestro tuviera el mayor empeño en que el resultado fueran cada día más satisfactorio. El maestro podía además, tener los registros y libros a la vista, apreciar con exactitud los méritos de cada discípulo y no incurrir en injusticias. Le servían también de recuerdo de aquellos alumnos con quienes por sus escasas facultades debían ser más cuidadoso y solicito en la enseñanza y explicaciones; $2^{\mathrm{a}}$, constituían un poderoso auxiliar para el maestro nuevo, por cuanto en ello se escribía con debida exactitud de los conocimientos, cualidades y demás condiciones escolares de sus discípulos, y podía, sin perder tiempo precioso, empezar tareas en donde hubiera concluido su antecesor. El maestro que no llevaba debidamente los libros y registros que se prescribían, incurría en irresponsabilidad por el tiempo que hacía perder al que lo fuera a reemplazar; $3^{\mathrm{a}}$, Eran fuentes de información para los funcionarios de instrucción pública, por cuanto en ellos podían averiguar en cualquier momento el estado y necesidades de las escuelas y determinar las medidas que se adoptaban para su mejoramiento ${ }^{62}$.

62 REVISTADE INSTRUCCIÓN PÚBLICADE COLOMBIA (1906). Periódico oficial destinado al fomento y a la Estadística de los Establecimientos de Enseñanza Pública. Número 12. Página 696 ss. 


\section{Libro de matrículas}

Todo maestro debía llevar indefectiblemente con aseo y puntualidad los siguientes libros, que estaba en el deber de exhibir siempre que se lo exigieran: el de matrículas, el diario, el de informes, el copiador de notas, el de visitas y actas de exámenes, el de programas, el de inventarios y el registro o resumen mensual de asistencia, aprovechamiento y conducta. El Libro de matrículas - La matrícula era la inscripción que hacía el maestro en el libro respectivo del nombre del alumno, su edad, el grado de instrucción que tuviera, el nombre del padre o madre o acudiente, y su residencia. Este libro debía tener siete columnas, que de izquierda a derecha se destinaban así: la primera, para el número de orden; la segunda, para la fecha de la inscripción; la tercera, para el nombre del alumno; la cuarta, para la edad; la quinta, para el lugar de su residencia; la sexta, para el grado de instrucción que poseía el niño, y la séptima, para el nombre del padre o madre o guardador del niño. El grado de instrucción se calificaba conforme a los datos que reposaban en la escuela del año anterior, o conforme a los que recibía el maestro del padre o guardador del niño, según que hubiera cursado $1 .^{\circ}, 2,{ }^{\circ}, 3$.», etc. años de las secciones elemental, media y superior, conforme al plan de estudios.

El maestro matriculaba todos los alumnos que se presentaban, vecinos del Distrito, mayores de siete años y menores de diez y ocho, que no padecieran enfermedades contagiosas ni de reconocida mala conducta. Cuando el número de alumnos matriculados pasaba de cien lo avisaba el maestro a la Junta de inspección local para que ella solicitara a la Dirección general de Instrucción Pública el nombramiento del Profesor o Subdirector. Al tiempo de matricular un alumno el maestro debía instruir al padre o acudiente en las obligaciones que contraía conforme a este Reglamento, y le haría firmar la siguiente diligencia, la cual debía cumplirse : « Los infrascritos, padres ó guardadores de los niños que matriculamos en esta escuela nos comprometemos á lo siguiente: 1.», á mandarlo diariamente al establecimiento durante todo el año escolar, en las horas de enseñanza, sin permitir que falten sino en caso de enfermedad o de imperiosa necesidad, dando aviso inmediato al maestro; $22^{\circ}$, á no permitir que los niños se mantengan en ocio por la calle durante el día, y no que salgan de la casa de las seis de la tarde en adelante; $3 .^{\circ}$, á no permitirles juegos interesados sino los gimnásticos y los propios para una sana distracción ó un inocente recreo; $4 .^{\circ}$, á mantenerlos siempre ocupados en oficios útiles en las horas que permanezcan bajo el hogar, pero de ninguna manera en las destilerías y ventas de licores; $5^{\circ}$, á no disimularles y antes bien corregirles inmediatamente las faltas graves de irrespetos ó dé cualquiera otra naturaleza que cometan los niños en el hogar ó en la calle ; $6 .^{\circ}$, á, suministrarles la mejor posible alimentación en las horas convenientes, y los útiles que no tenga la escuela; $7 .^{\circ}$, á contribuir eficazmente á que el niño dé estricto cumplimiento á los deberes escolares, haciéndole estudiar, y á que tenga esmerado cuidado en la conservación de los útiles y demás objetos que reciba; $8 .^{\circ}$, á responder del valor de los útiles y objetos que destruya ó que por descuido pierda el niño; $9 .^{\circ}$, á no retirar el niño de la escuela sino en caso de cambiar de domicilio la familia, ó de grave enfermedad del niño ó del padre ó madre ó guardador, debidamente comprobada cualquiera de estas causales y dando en todo caso aviso oportuno al maestro, y 10, á pagar por vía de multa, que ingresará al Tesoro 
municipal de instrucción pública, la suma de dos pesos oro si faltáremos á las obligaciones contraídas en esta diligencia, que para constancia firmamos, y sin que ocurran las causales justificativas enumeradas en la cláusula anterior. ${ }^{63}$

\section{Libro diario}

Como su nombre lo indica, este libro tenía por objeto llevar cuenta y razón exacta de los trabajos que diariamente se ejecutaban en la escuela. En él se anotaban : $1 .^{\circ}, 10$ que se realizaba en el día de los programas de cada asignatura $; 2 .^{\circ}$, el estado diario de la escuela, con las indicaciones o reclamos que debían hacerse a los padres y a las autoridades en el Ramo ; $3 .^{\circ}$, la preparación de las lecciones que debía dar el maestro en cada sección el día siguiente, según los programas respectivos $; 4,^{\circ}$, todos los datos que servían de guía para que la enseñanza fuera día por día más acertada y eficaz; $5 .^{\circ}$, los resultados de los exámenes que verificaban para graduar á los alumnos según sus aptitudes en cada sección, y todo cuanto al buen criterio del maestro le pareciera conducente a llevar la historia de los trabajos escolares. ${ }^{64}$

\section{Libro de informes}

En este libro se escribían todos los informes mensuales relativos a la marcha de la escuela que debía rendir á la Dirección general de Instrucción Pública por conducto del Inspector escolar. En este informe se tocaban los siguientes puntos : $1 .^{\circ}$, fecha de la posesión del cargo que ejercía $; 2{ }^{\circ}$, el número de alumnos matriculados, con distinción de sexos, en las escuelas alternadas, y el término medio de la asistencia diaria; $3 .^{a}$, parte recorrida del pensum reglamentario para cada sección y en cada materia, conforme á los programas respectivos $; 4 .^{\circ}$, alumnos que se hubieran distinguido por consagración al estudio, aprovechamiento y conducta; $5 .^{\circ}$, si los alumno asistían a misa en comunidad los días festivos y cumplían con los demás deberes religiosos; qué penas correccionales había aplicado y qué métodos de enseñanza había empleado de preferencia; 7,.el grado de instrucción de los educandos y su clasificación: por años y secciones conforme al plan de estudios reglamentario ; $8^{\circ}$, qué empleados han visitado el establecimiento, qué prevenciones les hicieron y si han sido cumplidas ; $9 .^{\circ}$, el estado en que se encontraban los edificios de las escuelas, los muebles y útiles de enseñanza; si tenían los suficientes o no; 10 , si las autoridades del lugar y los padres de familia les prestaban el apoyo moral y material necesario para la buena marcha del establecimiento ; si tenían verdadero interés ó se mostraban indiferentes; 11, si los sueldos les eran pagados puntualmente, y si el policía de las escuelas había cumplido debidamente sus deberes ; 12, si habían recibido el periódico oficial, ó qué números les faltan ; 13, debían acompañar también el resumen de la asistencia, conducta y aprovechamiento, de los niños durante el mes; 14, las reformas que convenían introducir para el mayor ensanche de la instrucción primaria, y todos cuantos datos fueran conducentes á la formación de la estadística escolar. Para que les sean ordenados los pagos de los sueldos los maestros

\footnotetext{
${ }^{63}$ Ibídem, p. 699
}

${ }^{64}$ Ibídem, p. 698. 
presentaban cada mes al empleado ordenador un certificado en papel común, del Tesorero ó Administrador de correos respectivo, en que constaba haber entregado en esa oficina el pliego que contenía el informe en referencia.

\section{Libro copiador de notas}

En este libro se copiaba, en orden cronológico, todas las comunicaciones oficiales que dirigía a empleados y particulares en cumplimiento de sus deberes y en orden al progreso de la escuela, pues debía dejar constancia aun de los más insignificantes actos oficiales. $^{65}$

\section{Libro de visitas y actas de exámenes}

Bien se comprende la importancia de este libro, como que en él debía constar la historia del deber cumplido. El maestro competente, diligente y consagrado no encontraba en él regaños ni prevenciones sino el estímulo de quien cumple sus deberes. Muy al contrario le sucedía al que carecía de dotes, de conocimientos, de métodos; al perezoso y abandonado, en una palabra, al que creía que se podía aceptar el magisterio con la intención única de ganar el sueldo. En este libro se escribían las diligencias de visita que practicaban los empleados del Ramo y las de los exámenes que se verificaban en el año lectivo, las que serían suscritas por los empleados que hubieran concurrido, y una copia debidamente autorizada remitía a el maestro a la Dirección general de Instrucción Pública.

\section{Libro de programas}

El programa tenía por objeto ahorrar tiempo y trabajo y acostumbrar al niño a ser metódico en su deber, por consiguiente, debía redactarse con mucho cuidado y de acuerdo con el plan de estudios reglamentario. En este libro se insertaban todos los programas de materias del año lectivo. En la distribución del tiempo se observaban estas, reglas: 1. ${ }^{a}$, debía proporcionar al maestro y al discípulo economía de tiempo ; 2. ${ }^{*}$, debía alternarse el estudio y las recitaciones; 3 .», debía repartirse bien el tiempo en ejercicios y descansos; 4.», los estudios y ejercicios difíciles se distribuían de modo que no se siguieran inmediatamente unos á otros, y los recreos serían a unas mismas hora para todos los alumnos.

\section{Libro de inventario}

En este libro se anotaba el estado general del local, el mobiliario, aparatos y demás objetos de la escuela, con indicación de buen estado y todos los útiles que para la enseñanza existían en la escuela y los que en lo sucesivo fueran recibiendo, con indicación de su procedencia. Anotaban también los útiles que a cada alumno distribuían, los cuales debía devolver al fin del año o al retirarse de la escuela. Como el maestro al retirarse debía hacer entrega formal del local, mobiliario y útiles, debía a su vez exigir

\footnotetext{
65 Ibídem, p. 697.
} 
que los padres de familia entregaran los útiles que sé les hubieran suministrado a sus hijos. Las diligencias de inventarios eran suscritas por el Presidente de la Junta de inspección o el empleado que hiciera la entrega, y por el maestro, y copia autorizada se enviaba a la Dirección de Instrucción Pública. Rregistro o resumen mensual. El maestro hacía mensualmente el resumen de faltas de asistencia del aprovechamiento y conducta de los meritos adquiridos, lecciones buenas y malas, cultura de todos los alumnos, el que envidiaba con el informe mensual a la dirección general de Instrucción Publica dejando copia auto realizadas en el libro que aquí se trata. ${ }^{66}$

Las faltas de asistencia se marcaban en la lista semanal con una línea vertical por la mañana y una horizontal al medio día; cuando era con permiso se le ponía al signo un punto: las de la semana se sumaban para reunirías con las de las otras semanas del mes; este resumen era muy importante y debía tener mucho cuidado al hacerlo. Era obligación de los maestros legajar por orden de fechas las notas oficiales y los periódicos que recibían y. conservarlos con esmero en el archivo. Era multado el maestro en un peso oro (\$1) por cada número del periódico que dejara de coleccionar.

El Inspector escolar pasaba a la Dirección general de Instrucción Pública, además de los datos e informes .que le remitieran los miembros e Inspectores locales, un informe anual que contenía : $1,^{\circ}$, el número de escuelas urbanas y rurales de niños y niñas y alternadas que hubieren funcionando en el territorio de su dependencia durante el año escolar con expresión del Distrito a que pertenecían;2. ${ }^{\circ}$,LosDistritosy caseríos en que no se hubieran abierto escuelas y las causas de esta deficiencia; $3 .^{\circ}$, los nombres de los maestros encargados de estas escuelas, el sueldo que disfrutan, su comportamiento, el grado que Tuviera o los medios que lo hubieran llevado a la dignidad de maestro y su competencia para el servicio escolar; $4 .^{\circ}$, la lista general de los alumnos que hubieran cursado en cada escuela y cada sección, calificación anual en las clases, aprovechamiento y conducta $; 5 .^{\circ}$, el estado administrativo y fiscal de cada escuela; sus capitales rentas y demás propiedades con que contaran y el modo como los habían adquirido; $6 .^{\circ}$, el número de visitas practicadas por él y demás funcionarios en el Ramo de instrucción pública primaria; $7 .^{\circ}$, Los cambios de personal que convinieran introducir para satisfacer mejor las necesidades de cada escuela y activar su desarrollo ; 8, Las escuelas que debían crearse, y $9 .^{\circ}$,todos los datos y observaciones que contribuían a esclarecer el estado y necesidades de la instrucción pública en el territorio que habían inspeccionado.

\section{CONCLUSIÓN}

El proyecto de Construcción de Nación no dependió solamente de la centralización política, sino que también el eje lo sostuvo la unidad espiritual, ideológica y lingüística. La Iglesia Católica se constituyó en uno de los fundamentos principales de la unidad.

\footnotetext{
${ }^{66}$ Ibídem, p. 699.
} 
En estos términos el Concordato fue el complemento necesario de la Constitución del 86 y lo que determino el quehacer del maestro de escuela. La estabilidad y unidad del catolicismo y su trayectoria en la cultura de la Nación; junto con el respeto por la autoridad fueron elementos indispensables para el proyecto político conservador de las tres primeras décadas del siglo XX. En esta perspectiva, los maestros, los métodos, tácticas y libros se organizaron conforme a los dogmas y la moral de la Religión Católica. Para la unidad política era necesaria la unidad ideológica y para ello, la Iglesia garantizaba la orientación católica de la educación y aportaba su aparato institucional, su organización, su estructura. Sin embargo, el proyecto político aseguró la suprema inspección y vigilancia, junto con el sostenimiento económico, pero con toda la responsabilidad en la iglesia. De esta manera, la reforma de Uribe hizo un esfuerzo para utilizar la educación como un medio para lograr la unidad ideológica de la Nación y afianzara por este camino, la presencia del poder central en la vida nacional. Las escuelas elementales contribuyeron significativamente en el proyecto de construcción de nación y en la organización de la estructura del Estado. Los maestros fueron el adalid del pensamiento conservador y aseguraron una ideología a través de los métodos, las tácticas y el sistema escolar implementado en las aulas.

\section{FUENTES}

Ley 39 de 1903. Artículo 1 al 5.

Decreto 491 de 1904.

Circular número 1025. Bogotá, julio 4 de 1905.

Hermano Gonzaga, Luís. (1913). Discurso pronunciado en la distribución de premios de la Escuela Normal Central de Institutores de Bogotá el 29 de noviembre de 1913. En: Revista la de Instrucción Pública de Colombia. Órgano del Ministerio del Ramo. Tomo XXVI. Bogotá, enero y febrero de 1913. Números 1y 2.

INFORME DEL DIRECTOR DE INSTRUCCIÓN PÚBLICA DEL DEPARTAMENTO DE CUNDINAMARCA (1905), en Revista de Instrucción Pública de Colombia. Periódico Oficial destinado al fomento y a la estadística de los establecimientos de enseñanza pública. (1905). Bogotá: Imprenta nacional.

Informe del Vicario Apostólico del Casanare, inspector de Instrucción Pública en las escuelas de ese territorio de la Intendencia del Meta, en el primer semestre del año 1905 Intendencia del Meta.

Ministerio de educación. (1959). Educación Colombiana 1903-1958. Imprenta Nacional, Bogotá.

República de Colombia. Ministerio de Instrucción Pública - Sección 1 $1^{\mathrm{a}}$ - Ramo de Negocios generales - Memorias de Revista de Instrucción Pública de Colombia. Periódico Oficial destinado al fomento y a la estadística de los establecimientos de enseñanza pública. (1905). Circular 1025. Bogotá: Imprenta nacional.

Revista de Instrucción Pública de Colombia. Periódico Oficial destinado al fomento y a la 
estadística de los establecimientos de enseñanza pública. (1905). Circular 1135. Bogotá: Imprenta nacional.

República de Colombia. Consejo Administrativo. (1905). Bogotá. 10 de Julio de 1905 número 21.

República de Colombia. Departamento de Bolívar, Caldas, Cundinamarca. Dirección de Instrucción Pública del Departamento. Sección de Instrucción Pública. Número 104. Cartagena, 22 de julio de 1905; Caldas, Gobernación número 19; Facatativá, número 95, en Revista de Instrucción Pública de Colombia. Periódico Oficial destinado al fomento y a la estadística de los establecimientos de enseñanza pública. (1905). Bogotá: Imprenta nacional.

República de Colombia - Departamento de Cundinamarca - Dirección de Instrucción Pública - Circular número 2 - Facatativá, Julio 6 de 1905. En: Revista de Instrucción pública (1905).

República de Colombia. Ministerio de Instrucción Pública.Ley 39 de 1903. Decreto Reglamentario 491 de 1904. Decreto número 267 de 1912. Resolución número 134 de 1906, por la cual se aprueba un Decreto 87 de 1906, 11 de septiembre, en Revista de la Instrucción Pública de Colombia. Tomo XX. Número 12. Bogotá, Diciembre de 1906.

\section{SELECCIÓN BIBLIOGRÁFICA}

CHARTIER, Anne Marie. (2004): Enseñar a leer y escribir. Una aproximación histórica. México, Fondo de Cultura Económica.

JARAMILLO URIBE, Jaime. (1980): El proceso de la educación. Manual de Historia de Colombia. Tomo III. Bogotá, Colcultura.

MELO, Jorge O. (1978): “La República Conservadora”, en Colombia Hoy. Bogotá Editorial Siglo XXI.

. (1978). La evolución económica de Colombia 1830-1900. Manual de Historia de Colombia. Tomo III. Bogotá, Colcultura.

MACHADO, Absalón. (1977). El café: de la aparcería al capitalismo. Editorial Punta de Lanza. Bogotá.

KALMANOVITZ, Salomón. (1978): El régimen agrario durante el siglo XIX. Manual de Historia de Colombia. Tomo II. Bogotá, Colcultura.

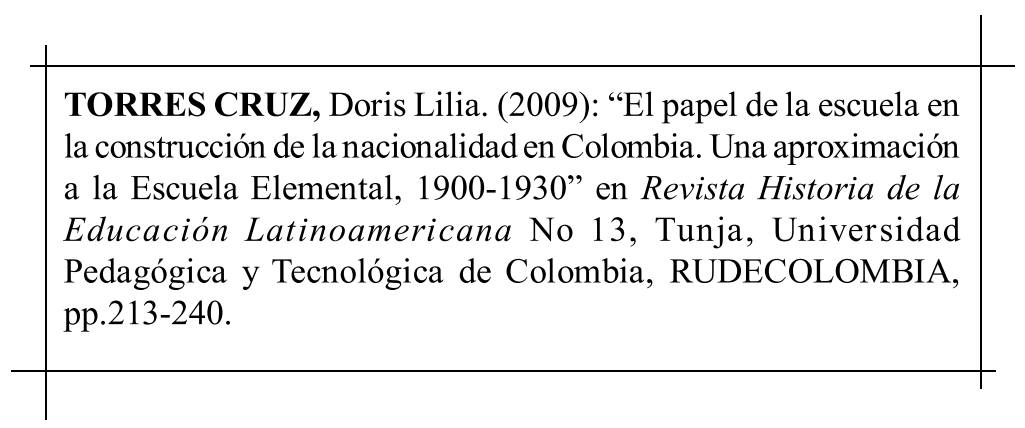

Rhela. Vol. 13. Año 2009, pp. 213 - 240 